\title{
SPRAWOZDANIA
}

DOI $10.15290 / \mathrm{sw} .2016 .16 .33$

\section{Międzynarodowa Konferencja Naukowa „Estetyczne modele literatury rosyjskiej", Białystok, 17-18 września 2015 r.}

W dniach 17-18 września 2015 r. w murach Wydziału Filologicznego Uniwersytetu w Białymstoku odbyła się międzynarodowa konferencja naukowa zorganizowana przez Katedrę Rosyjskiej Literatury Współczesnej Instytutu Filologii Wschodniosłowiańskiej UwB. W spotkaniu, które otworzyła Dyrektor IFW UwB Profesor dr hab. Wanda Supa, wzięli udział przedstawiciele licznych akademickich ośrodków krajowych, a także goście z Rosji, Białorusi i Ukrainy.

Inicjujący obrady wykład Пути и cross-nyти анализа современной русской лumepamyps Tatiany Knecht z Narodowego Uniwersytetu w Moskwie poświęcony został określeniu miejsca współczesnej literatury w historii literatury rosyjskiej. Po ustaleniu, czym jest sama współczesność, jak ją można rozumieć i definiować, autorka wystąpienia wskazała i porównała różnorodne metody analizy tekstów wywodzących się ze współczesnej literatury rosyjskiej. W dalszej kolejności prelegentka zwróciła uwagę na aktualność kategorii estetyki klasycznej (tj. piękno, harmonia, mimesis) w rozważaniach nad tekstami autorów współczesnych, a także przyjrzała się relacjom tychże kategorii z pojęciami i kategoriami antyestetyki (takimi jak brzydota, chaos, trasz).

Podczas dwudniowych obrad wygłoszono referaty poświęcone różnorodnym zagadnieniom doskonale wpisującym się w dyskusję nad tak zwaną „tradycją kluczową", istniejącą w świadomości pisarskiej, refleksji teoretycznej i krytycznoliterackiej. Wśród nich grupę najliczniejszą stanowiły wystąpienia, w których omówione zostały strategie twórcze poszczególnych pisarzy.

Tak więc, Nel Bielniak (Uniwersytet Zielonogórski) w swym wystąpieniu Piękno $i$ brzydota $w$ opowiadaniach Aleksandra Kuprina zwróciła uwage na fakt, iż w wielu utworach autora Jamy pojawia się motyw względności estetycznych ideałów. Pisarz często zauważa piękno, które nie rzuca się w oczy, a nawet doszukuje się go w rzeczach powszechnie uważanych za odrażające. Odnajdując pierwiastek piękna chociażby w martwym ciele ludzkim, Kuprin zabiera głos w kulturowo-filozoficznym dyskursie przełomu XIX i XX wieku.

Transformację tradycyjnych kategorii estetycznych piękna i brzydoty, tym razem w przestrzeni postmodernistycznej, prześledziła w swym referacie Междy прекрасным и ужасным: эстетика зла в повести А. Королёва «Голова Гоголя» 
Olga Joskiewicz (Grodzieński Uniwersytet Państwowy im. Janki Kupały). Badaczka wysunęła tezę o obecności w pisarskiej świadomości autora Nocnych głosów dwóch literackich tradycji: racjonalizmu doby Oświecenia i realizmu groteskowego. Centralne miejsce w estetyce A. Koroliowa zajmować mają kategorie zła, śmierci, tyranii, ale też dobra, piękna wolności. Oksymoroniczne zestawienie przeciwstawnych pojęć jest, zdaniem autorki wystąpienia, naczelną zasadą poetyki Koroliowa i świadczy o kognitywnym kryzysie autora.

Z kolei Irina Siereda z Białoruskiego Uniwersytetu Państwowego w Mińsku wygłaszając referat Tun «nодлинного» художника в прозе В. Маканина zwróciła uwagę na szczególną obecność w utworach rosyjskiego pisarza postaci twórców, ludzi utalentowanych, artystów. Kreując takich właśnie bohaterów Makanin przechodzi, jej zdaniem, proces samopoznania. Badaczka stawia tezę, iż makaninowskie portrety, zdolnych w szczególny sposób zgłębić naturę świata, postaci są zawsze autobiograficzne.

Niektóre analizy poświęcone były też badaniom nad żywotnością i funkcjonalnością modeli estetycznych literatury w ujęciu komparatystycznym. Iwona Mityk (Uniwersytet Jana Kochanowskiego w Kielcach) w wystąpieniu Anastazja Kamieńska Aleksandry Maryniny a Herkules Poirot $i$ Sherlock Holmes omówiła relacje pomiędzy powieściami Marininy a modelem klasycznej powieści detektywistycznej. Prelegentka poruszyła zarówno kwestię kreacji głównej bohaterki, jak i wykorzystania schematów konstrukcyjnych charakterystycznych dla tego gatunku, a modyfikowanych przez współczesnych twórców literatury na świecie.

Referat Этика русской классики в творчестве американского писателя ХХ века. Толстой, Достоевский и Джон Гарднер Natalii Sierżant z Białoruskiego Państwowego Uniwersytetu Pedagogicznego im. M. Tanka w Mińsku to próba recepcji motywów Dostojewskiego i Tołstoja w utworach Johna Gardnera. Prelegentkę zainteresowało zwłaszcza nowe ujęcie motywu zbrodni i kary, poszukiwania identyczności, korzeni, prawdy, idylliczny chronotop współczesnej amerykańskiej sielanki, a także polemika z estetycznymi poglądami Lwa Tołstoja w pracy Gardnera „On moral fiction (1978).

Jurij Piataczkow (Białoruski Pańtwowy Uniwersytet Pedagogiczny im. M. Tanka, Mińsk) w wykładzie Философия Красоть в поэтическом творчестве Ф.И. Тютчева и Э.Э. Дикинсон wskazał na realizację estetycznych założeń „poezji czystej" i medytacji poetyckiej w liryce F. Tiutczewa i E. Dickinson w odniesieniu do szkoły parnasistów. Prelegent zwrócił uwagę na nowatorski podejście i oryginalne realizacje konkretnych założeń teoretyków sztuki czystej w twórczości obojga poetów.

Rozważania na temat obecności estetycznych modeli znanych z tzw. kultury popularnej w dziełach rosyjskiego klasyka przedstawił w referacie „Tajemnica owa wielka jest" - Antoniego Czechowa polemika z love story mgr Artur Sadecki (Uniwersytet Marii Curie-Skłodowskiej w Lublinie). Autor wystąpienia, nawiązując do teorii uniwersaliów literackich Patricka C. Hogana, według której istnieją uniwersalne wzorce narracyjne, oparte na stałych reakcjach emocjonalnych odbiorcy, dokonał analizy narratologiczno-kognitywnej kilku opowiadań rosyjskiego pisarza, wskazując na mechanizmy literackiej „polemiki” Czechowa z tradycyjną narracją romantyczną i jej emocjonalną recepcją. Zdaniem badacza Czechow kończy epokę 
wielkich love story w literaturze rosyjskiej XIX wieku i tym samym otwiera pole do modernistycznych poszukiwań w sferze uczuciowej.

W czterech, spośród zaprezentowanych na konferencji, artykułach podjęto próbę refleksji nad strukturą modeli estetycznych w rosyjskim dramacie. Rozważania nad utworami, które łączy nie tylko polemika ze strategią dyskursu miłosnego realizująca się w prześmiewczej kreacji postaci Don Juana, ale tė rok ich powstania (2014) podjęła w wystąpieniu Schemat - Klisza - Reinterpretacja? Don Juan $w$ najnowszej dramaturgii rosyjskiej Jadwiga Gracla (Uniwersytet Warszawski). Zdaniem prelegentki oba omawiane utwory (jeden z nich to komedia, drugi to tragedia) można rozpatrywać jak lustrzane odbicia.

Próbę zarysowania autorskich strategii dramaturgów rosyjskojęzycznych Białorusi i Rosji końca XX i początku XXI wieku w aspekcie porównawczym w wystąpieniu Эстетические модели Е. Поповой и русских драматургов кониа XXначала XXI вв. podjęła reprezentująca Białoruski Państwowy Uniwersytet w Mińsku Jeliena Liepiszewa. W oparciu o analizę kreacji bohaterów, zarysowanie konfliktu, organizację chronotopu autorka postawiła tezę, iż praktyka twórcza części dramaturgów (E. Popowa, A. Galin, M. Arbatowa, N. Kolada) świadczy o ich dążeniu do odnowienia tradycji realistycznej, innych zaś o zbliżaniu się do estetki modernizmu (L. Pietruszewska, A. Kazancewa) czy postmodernizmu (L. Pietruszewska, O. Kuczkina).

Problem języka, jako subiektu w przestrzeni współczesnego rosyjskiego dramatu, był przedmiotem zainteresowania Macieja Pieczyńskiego (Uniwersytet Szczeciński). Jego wystąpienie Текст как персонаж новейшей русской драматургии było próbą odpowiedzi na pytanie o miejsce samego tekstu w strukturze współczesnej sztuki teatralnej. Zdaniem prelegenta w dramatach wykorzystujących dokumentalną technikę Verbatim nadrzędna rola słowa sprawia, iż zasada mimesis ustępuje miejsca diatezie.

Technice Verbatim w teatrze rosyjskim poświęciła swoje wystąpienie także Paulina Charko-Klekot (Uniwersytet Śląski w Katowicach). Jej referat Technika VERBATIM - przyszłość dramatu dokumentalnego? Jelena Isajewa $i$ jej teatr non-fiction to próba analizy twórczości autorki sztuki Dok.tor, a także porównania wypracowanego przez nią modelu dramatu dokumentalnego z osiągnięciami innych twórców tego gatunku, zwłaszcza dramaturgów wywodzącymi się z Teatru.doc.

Jeden z wygłoszonych referatów omawiał technikę reportażu. Sylwia Kryńska-Kawka (Uniwersytet Marii Curie-Skłodowskiej w Lublinie) w wystąpieniu Wojna widziana oczami dzieci, na podstawie reportażu Swietlany Aleksijewicz „Ostatni świadkowie. Utwory solowe na głos dziecięcy" opisała dążenie autorki dokumentu do przekazania prawdy o cierpieniu w obliczu wydarzeń II Wojny Światowej poprzez przedstawienie ich czytelnikowi w relacjach dzieci.

Część wystąpień poświęcona była refleksji uogólnionej i teoretycznoliterackim rozważaniom na temat estetycznych modeli mających wpływ na obraz współczesnej literatury rosyjskiej. W referacie Kуртуазные маньеристы как апологеть чистого искусства Tatiana Daniłowicz z Białoruskiego Państwowego Uniwersytetu Pedagogicznego im. M. Tanka podjęła rozważania nad specyfiką rozumienia sztuki czystej w manifestach Orderu kurtuazyjnych manierystów - rosyjskiego ugrupowa- 
nia literackiego lat 80. XX wieku, zestawiając takie podejście z zachodnioeuropejską i rosyjską tradycją interpretacji tej koncepcji.

Rozważania na temat estetycznych modeli mających wpływ na obraz współczesnej literatury rosyjskiej na płaszczyźnie stricte teoretycznej kontynuowane były w referacie По ту сторону «достоверности»: документальный монтаж в современной русской литературе Andreja Tesli (Uniwersytet Państwowy Oceanu Spokojnego w Chabarowsku). Rosyjski badacz zwrócił uwagę na aktywne odrodzenie się w literaturze rosyjskiej lat 90. gatunku „montażu dokumentalnego”, który wykorzystuje dziś „,wiarygodność” jako środek stylistyczny. Poprzez ukrycie osoby autora autentyczność zostaje w nim oddzielona od „efektu autentyczności”, co prowadzi do strategii „delikatnego zarządzania” czytelniczymi interpretacjami ”.

$\mathrm{Na}$ Konferencję zgłoszono także inne referaty:

Irena Rudziewicz (Uniwersytet Warmińsko-Mazurski) w wystąpieniu zatytułowanym Горьковские эстетические категории в рассказах Василия Шукшина omówiła zasady modelowania świata w utworach autora Cudaka.

Tatiana Awtuchowicz (Uniwersytet Przyrodniczo-Humanistyczny w Siedlcach) w referacie Прекрасное и безобразное в поэтическом мире Марии Степановой przedstawiła wzajemne relacje i oddziaływanie na siebie obecnych w omawianej przez nią poezji kategorii estetycznych piękna i brzydoty w aspekcie tradycji i nowatorstwa.

Irina Plechanowa (Irkucki Uniwersytet Państwowy), ref. Игра в примитив как вектор выхода из тупика постмодернизма (поэзия и проза 2000-х), zwróciła uwagę na zmiany, jakie dokonały się w najnowszej sztuce rosyjskiej (koncentracja na autorefleksji, wyzwolenie się od związków z realnym życiem) i ich następstwach (problemy z ontologicznym potwierdzeniem statusu twórcy i jego działalności) prowadzące do zwrotu w stronę stylistyki prymitywizmu (gra z prostą formą).

Olga Trofimowa (Państwowy Uniwersytet w Tiumeniu), ref. Серия «Приключения сестры Пелагии» Бориса Акунина и дилогия «В лесах» $и$ «На горах» Андрея Печерского: общее и особенное, podjęła próbę analizy porównawczej modeli estetycznych typowych dla wymienionych w tytule referatu „zawołżańskich” utworów literatury pięknej XX i XXI wieku koncentrując się na założeniach strukturalno-kompozycyjnych i typologii postaci.

Dr Lilija Cibizowa (Wszechrosyjski Państwowy Uniwersytet Kinematografii im. S.A. Gierasimowa), ref. Жизнь как трагедия в прозе Андрея Платонова и кинематографе Александра Сокуров, rozpatrzyła specyfikę funkcjonowania kategorii „tragiczne” w języku literatury pięknej i sztuce wizualnej, zwracając uwage na dialog, w jaki wstępują obie sztuki, stwarzając tym samym nowe możliwości pojmowania tragizmu ludzkiego istnienia.

Olga Agaponowa (Grodzieński Państwowy Uniwersytet im. Janki Kupały), ref. Лирический дискурс Олеси Николаевой: от жанра/модальности $к$ типам коммуникации, poświęciła swoje wystąpienia modelom estetycznym w przestrzeni rosyjskiej poezji.

Aliona Bogdziewicz (Grodzieński Uniwersytet Państwowy im. J. Kupały), ref. Книга спасенная и спасающая: соииокультурный анали, omówiła problem funkcjonowania dzieła literackiego we współczesnym społeczeństwie. 
W programie konferencji znalazły się także wystąpienia pracowników Uniwersytetu w Białymstoku: Eschatologiczny wymiar nocy w późnej poezji Afanasija Feta - Joanny Dziedzic, Estetyczna polifonia w dramatach Władimira Sorokina - Weroniki Biegluk-Leś, «Новый реализм» - вариант Захара Прилепина - Ewy Pańkowskiej, Między buntem a ucieczka. Źródła absurdu w opowiadaniu Władimira Sorokina „Nastia” - Agnieszki Baczewskiej-Murdzek.

Z uwagi na skrótowy charakter niniejszego opracowania przedstawiono w nim jedynie główne tezy wystąpień i naszkicowano przebieg obrad w okrojonej formie.

Z uwagi na kameralny charakter Konferencja stanowiła dobre forum dyskusji i wymiany poglądów. Organizatorzy wyszli z założenia, iż specjalistyczne spotkanie okaże się bardziej efektywne niż rozległe tematycznie, przekrojowe konferencje i przyczyni się do zacieśnienia współpracy naukowej różnych ośrodków. Wygłoszone na nim referaty będą zebrane w monografii naukowej, która zostanie przygotowana w 2016 r.

Agnieszka Baczewska-Murdzek Biatystok 